\title{
Decomposition in salt marsh ecosystems: phenolic dynamics during decay of litter of Spartina alterniflora
}

\author{
John O. Wilson ${ }^{1 *}$, Robert Buchsbaum ${ }^{1}$, Ivan Valiela ${ }^{1}, \&$ Tony Swain ${ }^{2}$ \\ 'Boston University Marine Program, Marine Biological Laboratory, Woods Hole, Massachusetts 02543, USA \\ ${ }^{2}$ Department of Biology, Boston University, 2 Cummington Street, Boston, Massachusetts 02215, USA
}

\begin{abstract}
Loss of weight and change in concentration of soluble phenolics, bound phenolics, lignins, and cell wall material were followed over 2 yr of decay in 4 types of litter of Spartina alterniflora. The pattern of weight loss showed rapid leaching during the first month, temperaturedependent decay during the first year, and little further loss during the second year. Soluble phenolics were lost throughout decomposition. Initially some soluble phenolics may become attached to cell walls; absolute increases in bound phenolics were observed in low marsh litters during the first 2 wk of decay. Lignins were lost at the slowest rate from litter material and increased in relative concentration during decay. Intraspecific differences in litter quality were small, and did not alter the pattern of decomposition among the 4 types of litter. Changes in chemical composition of litter during decay, however, were major controls of decay rates during the second and third phases of decomposition. Decreasing weight loss correlated with increasing lignin and nitrogen content. The increase in nitrogen presumably reflected synthesis of refractory nitrogen-enriched complexes. As decay continued, the litter became progressively enriched in recalcitrant lignin and nitrogen-enriched complexes and little further loss of organic matter occurred.
\end{abstract}

\section{INTRODUCTION}

The rate of decomposition of plant litter in any ecosystem is determined by interactions between the litter, environmental conditions, detritus-feeding animals and microorganisms (Swift et al. 1979, White \& Trapani 1982). The chemical composition of the litter is of great importance in determining the extent and rate of litter decomposition. Phenolic compounds in particular are thought to play a key role, markedly reducing the rate of plant litter degradation (Davies 1971 , Schlesinger 1977, Singh \& Gupta 1977).

Grasses generally contain substantial concentrations of soluble phenolics, cell wall bound phenolics, and lignins (Hartley \& Jones 1977). These compounds may reduce the susceptibility of plant litter to attack by decomposers (Swain 1978). In this paper we examine the relation of these 3 types of phenolic compounds and decay rates in litter of salt marsh cordgrass Spartina alterniflora.

- Present address: M/S 483, Langley Research Center, National Aeronautics and Space Administration. Hampton, Virgina 23665, USA
The chief soluble phenolic acids in Spartina alterniflora are cinnamic acid esters of glucose (Valiela et al. 1979). These phenolics are stored in cell vacuoles and act as antimicrobial agents and herbivore deterrents (Rice \& Pancholy 1974, Woodhead \& Cooper-Driver 1979, Buchsbaum et al. 1984), and possibly as substrates for flavonoid and lignin synthesis (Stafford 1974, Akers et al. 1977). Such compounds are stable and persist after senescence of the plant and can inhibit detritivores, as shown for litter of $S$. alterniflora (Valiela et al. 1979).

The phenolic compounds bound by esterification to lignins, cellulose, and hemicelluloses in cell walls of Spartina alterniflora are mainly hydroxycinnamic acids (Hartley \& Jones 1977, Collins et al. 1981). These compounds, especially $p$-coumaric acid, may be lignin precursors, but their main importance in the context of litter decomposition is that they may inhibit the enzymatic hydrolysis of the cell wall polysaccharides to which they are attached (Hartley \& Jones 1977).

Lignins, a third group of phenolics, are heteropolymers that form close associations with cell wall polysaccharides. They mechanically strengthen cell walls and 
render them more resistant to microbial attack or animal digestion (Cowling \& Brown 1969). Lignins therefore can slow the rate of litter decomposition (Peevy \& Norman 1948, Bollen 1953, Meentemeyer 1978).

Biochemical factors other than the concentrations and types of phenolic compounds present affect the rates of decomposition of plant litter; one such factor is nitrogen content. The effect of nitrogen is presumably due to stimulation of microbial activity (Witkamp 1966, Satchell \& Lowe 1967, Harrison 1982, Marinucci et al. 1983, Valiela et al. 1985). The effect also may be the result of an interaction with phenolic compounds. In a study of the effect of litter chemistry on food choice by salt marsh detritivores, high nitrogen concentrations overcame the inhibitory effect of phenolic acids on feeding by detritivorous snails (Valiela \& Rietsma 1984, Valiela et al. 1984).

In this paper we examine the effects of certain chemical components (phenolics and nitrogen) on rates of decay of salt marsh litter. We hypothesized that intraspecific variation in chemical make-up may significantly influence rates of decomposition. The effects of intraspecific differences in litter quality on decay rates were examined by comparing decay in litterbags containing litter of the tall and short forms of Spartina alterniflora from fertilized and control salt marsh plots. The 2 forms are ecophenotypes (Shea et al. 1975, Valiela et al. 1978) that grow at 2 different elevations, designated here as creekbank (CB) and low marsh (LM). The creekbanks are at lower elevations than the low marsh, but elevation has only a small influence on the rate of decay (Valiela et al. 1985). The use of litter from the 4 treatments thus permitted an examination of the decomposition of litter from a single species of marsh grass containing different initial amounts of percent nitrogen.

\section{METHODS}

Great Sippewissett Marsh is located on the western shore of Cape Cod, Massachusetts, USA. Since 1971, a series of experimental plots have been maintained on the marsh to which fertilizers are added (Valiela et al. 1976). Two control plots (CB C; LM C) and 2 plots (CB $X F$; LM XF) that received $75 \mathrm{~g} \mathrm{~m}^{-2} \mathrm{wk}^{-1}$ of a mixed fertilizer (N: $10 \%$; P: $6 \%$; K: $4 \%$ ) from March through November were used in this study. The fertilized plots produce litter with nitrogen contents higher than untreated control plots (Vince et al. 1981, Valiela et al. 1985).

In October 1979, senescent culms of Spartina alterniflora were collected from fertilized and control plots located in creekbank (CB) and low marsh (LM) areas of the study site. Air-dried culms $(50 \mathrm{~g})$ were placed whole in $4 \mathrm{~mm}$ mesh nylon litterbags, and replaced in their respective plots. The size of the mesh admitted all but the largest detritivores (fish and crabs) but was small enough to retain litter. Litter bags were sampled after $0.5,1,5.5,9.5,13$, and 23 mo. Two litter bags per site were collected on each date. Upon sampling, accumulated sediment was gently rinsed from the litter with running seawater and the litter dried at $60^{\circ} \mathrm{C}$ and ground to pass a 60 mesh $(0.250 \mathrm{~mm})$ sieve.

Soluble phenolics in the litter were determined by extraction of $250 \mathrm{mg}$ of the powder in $10 \mathrm{ml}$ of $80 \%$ aqueous methanol for $10 \mathrm{~min}$ at $80^{\circ} \mathrm{C}$, and then the mixture was allowed to cool for $20 \mathrm{~min}$ at room temperature. After centrifugation the supernatant was separated and the plant slurry re-extracted as above. The 2 extracts were combined and reduced by evaporation to $10 \mathrm{ml}$. The concentration of soluble phenolics in the extract was then estimated by comparing the absorption at $324 \mathrm{~nm}$ to that of a ferulic acid standard (Hartley \& Jones 1977).

The residue was then treated further to obtain cell wall material, containing mainly polysaccharides, cellwall bound cinnamic acids, proteins, and lignins. Lipids were removed by washing the residue from methanol-extractions in $10 \mathrm{ml}$ of chloroform/ether (3:1 $\mathrm{v} / \mathrm{v}$ ) for $30 \mathrm{~min}$ at room temperature, and then in $10 \mathrm{ml}$ of ether alone for $30 \mathrm{~min}$ at room temperature. This cell wall material was dried and used for further assays of cell wall-bound phenolics and lignins.

Determination of total bound phenolic acids started with hydrolysis of $100 \mathrm{mg}$ of cell wall material in $1 \mathrm{~N}$ $\mathrm{NaOH}$ for $4 \mathrm{~h}$ at room temperature under nitrogen to free the bound phenolic acids. The mixture was filtered, the filtrate acidified to $\mathrm{pH} 2.0$, and the phenolic acids extracted into ether (Hartley \& Jones 1977). Total bound phenolic acids were quantified by measuring the UV absorption of the bound phenolic acid fraction at $308 \mathrm{~nm}$ (where a distinct maximum occurred) and comparing this to a standard curve of absorption at $308 \mathrm{~nm}$ of known quantities of p-coumaric acid. All analyses were carried out in triplicate.

Concentrations of individual bound phenolic acids were determined by gas chromatography. Following the base hydrolysis and extraction of bound phenolics into ether described above, the ether was removed under a stream of nitrogen gas. The phenolic acids remaining were then converted to trimethylsilyl derivatives and analyzed on a $200 \mathrm{~cm}$ by $2 \mathrm{~mm}$ i.d. glass column filled with $3 \%$ OV-25 coated on a $60-80$ mesh Chromosorb W support installed in a Varian 3700 gas chromatograph fitted with a flame ionization detector (Vande Casteele et al. 1976). The column was temperature programmed from 100 to $260^{\circ} \mathrm{C}$ at $6 \mathrm{C}^{\circ}$ $\min ^{-1}$ with an initial hold of $5 \mathrm{~min}$.

Lignin content of litter was established by digestion of extracted cell wall material with acetyl bromide and 
subsequent measurement of absorbance at $280 \mathrm{~nm}$ (Johnson et al. 1961, Morrison 1972a). Lignin concentrations were then determined by comparing the UV absorbance $(280 \mathrm{~nm})$ to that of a lignin standard consisting of a preparation of cell wall material from Spartina alterniflora. Lignin content of this primary standard was originally determined gravimetrically by a 2 -stage hydrolysis procedure using $72 \%$ and $1 \mathrm{~N}$ sulfuric acid (Effland 1977).

Nitrogen concentrations were adapted from Valiela et al. (1985) and corrected to an ash-free dry weight basis.

Ash content of each sample of the litter was determined by combustion at $550^{\circ} \mathrm{C}$ for $3 \mathrm{~h}$ and dry weights $\left(60^{\circ} \mathrm{C}\right)$ of the litter and concentrations of litter components were corrected to an ash-free dry weight (AFDW) basis. Litter components are reported as percent of initial content of each component remaining in the litter at each sampling time. Furthermore, for lignin, the relative concentration ( $\%$ AFDW) is also given.

The AFDW provides a close approximation of the organic content of the litter and was used in the analysis of decomposition. The decomposition rate was expressed as the percentage of the original AFDW lost during each sampling period. In addition, decomposition was modeled as a negative exponential function (Olson 1963), using the equation:

$$
\ln \left(\mathrm{W}_{\mathrm{t}} / \mathrm{W}_{\mathrm{o}}\right)=-k \mathrm{t},
$$

where $\mathrm{W}_{0}=$ the original AFDW; $\mathrm{W}_{\mathrm{t}}=$ percentage AFDW remaining after time $\mathrm{t} ; \mathrm{t}=$ time (in days). $k$ values were determined as the slope of the linear regression of $\ln W_{t}$ vs time.

\section{RESULTS AND DISCUSSION}

\section{Total weight loss}

The pattern of weight loss from litter of Spartina alterniflora can be described as occurring in leaching. decomposer, and refractory stages (Odum et al. 1973, Valiela et al. 1985). The loss of organic matter from litter had a rapid initial stage (Fig. 1), during which 20 to $40 \%$ of the original amount of material was removed. This initial stage presumably involved leaching of soluble organic materials (Nykvist 1959, Odum \& Heywood 1978, Haines \& Hanson 1979, Lee et al. 1980, Montagna \& Ruber 1980).

The possibility that loss of litter fragments from litter bags occurring during handling, transport, and installation of the bags in the field contributed to the losses of organic matter occurring initially was examined (Valiela et al. 1985). Changes in litter weight due to these procedures were very small (i.e. less than $1 \%$ of

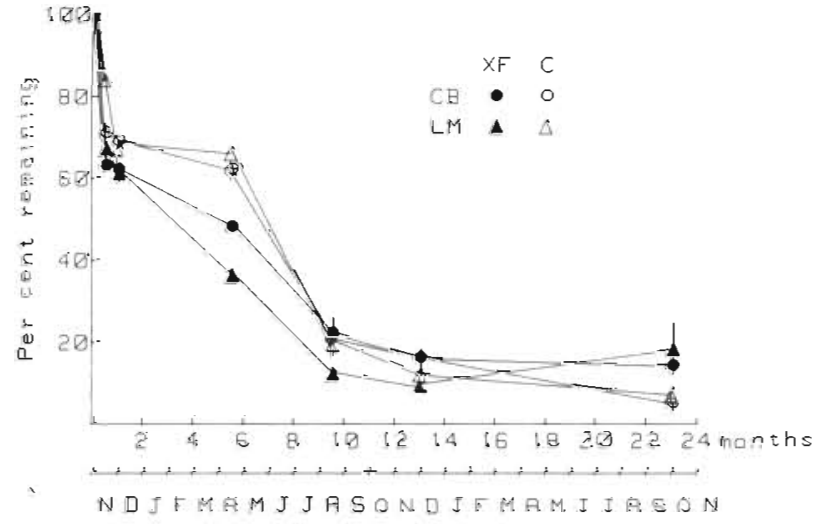

Fig. 1. Percent of initial ash-free dry weight remaining in litterbags placed in creekbank (CB) and low marsh (LM) habitats. Within each habitat fertilized (XF) and control (C) litter were used in separate treatments. There were 2 replicates per treatment. Values are means $\pm \mathrm{SE}$

the initial litter weight) and such losses cannot account for the rapid disappearance of material occurring during this period.

The rate of weight loss slowed during a second phase of decay which presumably depended on fungal and bacterial attack on structural components of the litter. Temperature affects rates of litter decomposition (Witkamp \& Van der Drift 1961, Suberkropp et al. 1975, Wiegert \& McGinnis 1975, Christian 1984); thus the slowing of the decay rate of litter in the winter and subsequent increase in the spring was expected (Fig. 1). As the decay of litter continued into the warmer months, the amounts of material remaining in the litterbags converged.

In the third stage of litter decomposition there was little further loss of weight. In fact, LM XF litter showed a gain in AFDW during the second year. Increases in mass of litter remaining have been observed in other studies, and may be due to sampling error, or growth of the epiphyte community, but the causes of such increases need further investigation (Christian 1984).

Decomposition rates were similar for the 4 types of litter of Spartina alterniflora (Table 1). $k$ values ranged

Table 1. Decomposition rate constant, $k$, with $95 \%$ confidence interval and coefficient of determination $\left(\mathrm{I}^{2}\right)$ for fertilized and control litters from CB and LM habitats. $k$, the decomposition rate constant, is the slope of the linear regression of ln AFDW vs time for the 23 mo period of the study

\begin{tabular}{|lccc|}
\hline Litter type & \multicolumn{1}{c}{$k$} & $\mathrm{r}^{2}$ & $\mathrm{n}$ \\
& $\left(\mathrm{d}^{-1}\right)$ & & \\
\hline CB C & $-0.0042( \pm 0.0009)$ & 0.97 & 14 \\
CB XF & $-0.0028( \pm 0.0013)$ & 0.85 & 14 \\
LM C & $-0.0040( \pm 0.0014)$ & 0.92 & 14 \\
LM XF & $-0.0028( \pm 0.0027)$ & 0.59 & 14 \\
\hline
\end{tabular}


only from -0.003 to -0.004 , and did not differ significantly except between $\mathrm{CB} C$ and $\mathrm{CB}$ XF litters $(\mathrm{t}=3.82 ; \mathrm{p}<0.005)$. Use of the $k$ value to express the decomposition rate assumes a constant loss of material leading to an inverse exponential pattern of decay (Olson 1963), and does not allow for changes in the biological, chemical, and physical processes involved in the loss of litter during the different phases of decay. Nevertheless, the single decay coefficient of the simple exponential model is useful for comparison of decomposition curves (Wieder \& Lang 1982, Brock et al. 1985), and this model provided a reasonable fit to the data.

\section{Soluble phenolics}

Initial concentrations of soluble phenolics in $\mathrm{CB}$ and LM litter were not significantly different (t-test; $\mathrm{p}>0.05$ ) and averaged $5.7 \mathrm{mg} \mathrm{g}^{-1}$ AFDW. Amounts of soluble phenolics remaining in XF and $C$ litters from each habitat were similar at most times during decay.

Loss of soluble phenolics occurred rapidly during the leaching phase. $\mathrm{CB}$ litter is subject to greater tidal flushing than LM litter (Valiela et al. 1985) and, during the first month of decay, lost about 60 to $70 \%$ of the initial content of soluble phenolics compared with $45 \%$ from LM litter (Fig. 2). Rates of loss slowed during the winter, but LM litter continued to lose soluble phenolics and at a faster rate in winter than CB litter such that by $6 \mathrm{mo}$, the \% soluble phenolics remaining were similar between $\mathrm{CB}$ and $\mathrm{LM}$. This may have been the result of continued leaching of soluble phenolics from LM litter of material already leached from $C B$ litter. After 9.5 mo of decay, the amounts of soluble phenolics remaining in the different litters converged. Only $10 \%$ of the original amounts of soluble phenolics remained, and little further loss occurred.

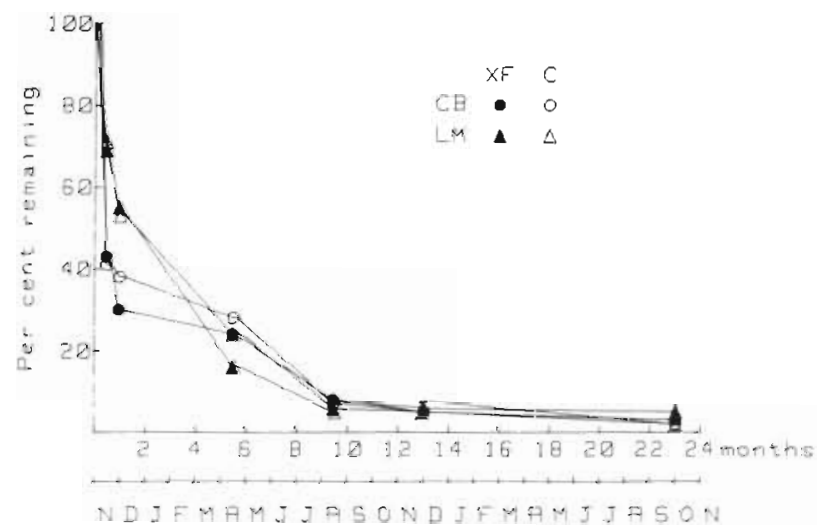

Fig. 2. Percent of initial amount of soluble phenolics remaining in the litter from fertilized (XF) and control (C) plots within creekbank (CB) and low marsh (LM) habitats. Values are means $\pm \mathrm{SE}$ of duplicate treatments

\section{Cell wall material}

Cell wall material accounted for insoluble components remaining in the litter. This fraction, consisting largely of hemicelluloses, cellulose, and lignins, initially made up about $83 \%$ of the AFDW of CB litter and $75 \%$ of the AFDW of LM litter. Concentrations of cell wall material were similar in XF and $\mathrm{C}$ litters from each habitat.

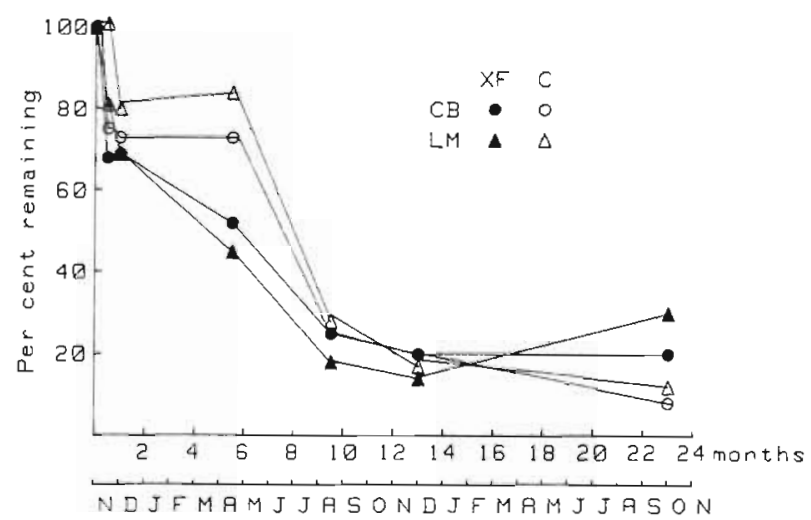

Fig. 3. Percent cell wall material remaining in fertilized (XF) and control (C) litter placed in creekbank (CB) and low marsh (LM) sites. Values are means $\pm \mathrm{SE}$ of duplicate treatments

The pattern of loss of cell wall material was variable (Fig. 3), but similar to that of organic matter (AFDW). During the leaching phase 20 to $35 \%$ of the original amounts of cell wall material were lost. Loss of cell wall material from litter slowed during winter and increased in warmer months. After $9 \mathrm{mo}$, only 18 to $30 \%$ of the initial amount of cell wall material remained and little further loss occurred.

\section{Bound phenolics}

Concentrations of cell wall-bound phenolics were $5.5 \mathrm{mg} \mathrm{g}^{-1}$ AFDW in CB litter and $2.8 \mathrm{mg} \mathrm{g}^{-1}$ AFDW in LM litter. Fertilization did not affect the bound phenolic concentrations in the litter.

The pattern of loss of bound phenolics was irregular with both apparent losses and gains occurring over the first 6 mo of decay (Fig. 4). Initial absolute increases were observed in LM litter and are similar to those observed in other studies for lignin (Kaushik \& Hynes 1968, Triska et al. 1975, Suberkropp et al. 1976) and nitrogen (Mikola 1955, King \& Heath 1967, Odum et al. 1979). These increases may have resulted from the formation of insoluble complexes from the binding of proteins and soluble phenolics present in the plants at the time of senescence (Handley 1961). No such increase occurred during the first 2 wk of decay in $\mathrm{CB}$ 


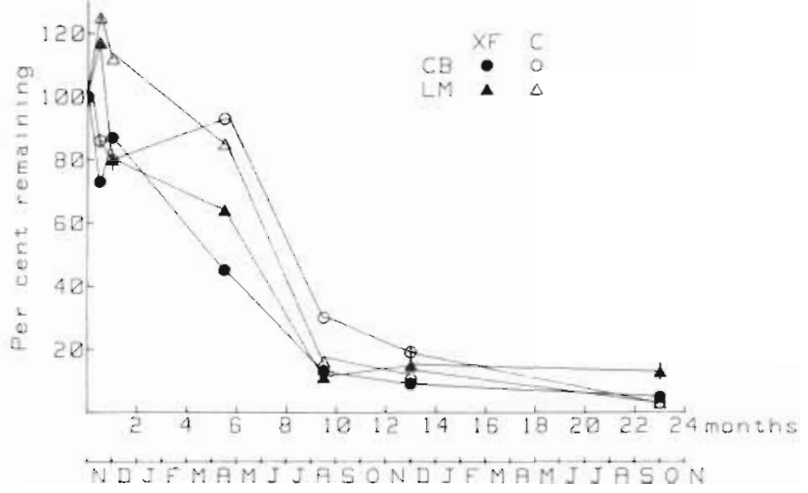

Fig. 4. Percent bound phenolics remaining in fertilized $(X F)$ and control (C) litter placed in creekbank (CB) and low marsh (LM) sites. All treatments were run in duplicate; values are means $\pm \mathrm{SE}$

litter, which was exposed to greater tidal flushing and is subject to a more rapid loss of soluble phenolics than LM litter (Fig. 2). The loss of nearly twice as much soluble phenolics from CB litter during the first $2 \mathrm{wk}$ of decay may contribute to the initial lack of an absolute increase in bound phenolics in CB litters.

Bound phenolics decreased during the decomposer phase up to about $1 \mathrm{yr}$ (Fig. 4), and the amounts remaining in the litters eventually converged. After a year of decay, little further loss occurred.

Use of UV absorption to quantitatively determine the concentrations of soluble and bound phenolics in plant litter assumes that the constituents of these pools are equally susceptible to decomposition, and that no submolecular changes have occurred that might alter the molar absorptivity of these compounds. In the case of bound phenolics, determination of concentrations of individual phenolic acids in $\mathrm{CB} X \mathrm{XF}$ and $\mathrm{C}$ litters by gas chromatography provided a check on these assumptions. Bound phenolics in these litters consisted primarily of $p$-coumaric and ferulic acid in a ratio of approximately $2: 1$. These 2 phenolic acids accounted for 75 to $97 \%$ of the bound phenolics in CB C litter and
61 to $150 \%$ of the bound phenolics in CB XF litter over the course of the study (Table 2). There were no significant trends in the ratio of these 2 phenolic acids to the total amount of bound phenolics over time, indicating that no selective changes occurred in the relative composition of the bound phenolic pool during decomposition. Thus the basic assumptions for the use of UV absorption to quantitatively determine concentrations of bound phenolics in litter of Spartina alterniflora appear to be satisfied.

\section{Lignins}

Litter of the 4 types of Spartina alterniflora used in this study initially contained 11 to $12 \%$ lignin (Fig. 5b), somewhat less than concentrations of lignin (18 to $21 \%$ ) reported for standing dead $S$. alterniflora

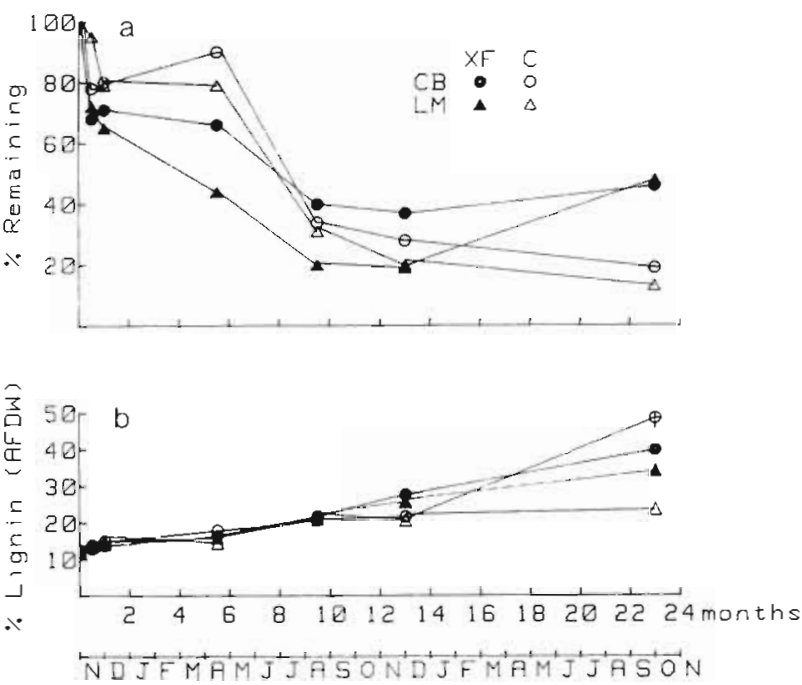

Fig. 5. Percent lignin remaining in litter. (a) Percent of initial lignin content remaining in litter. (b) Lignin concentration $(\%$ AFDW) in recovered litter. Litter from fertilized (XF) and control (C) plots was placed in creekbank (CB) and low marsh

(LM) habitats. Results are means $\pm \mathrm{SE}$ of 2 replicates

Table 2. Percentage of total bound phenolics in litter from creekbank (CB) habitats accounted for by $p$-coumaric and ferulic acids bound to cell walls over 23 mo of decomposition

\begin{tabular}{|c|c|c|c|c|c|c|}
\hline \multirow{3}{*}{$\begin{array}{l}\text { Litter age } \\
\quad \text { (mo) }\end{array}$} & \multicolumn{6}{|c|}{$\%$ of total bound phenolics } \\
\hline & \multicolumn{3}{|c|}{ CB C litter } & \multicolumn{3}{|c|}{ CB XF litter } \\
\hline & $\begin{array}{c}p \text {-coumaric } \\
\text { acid }\end{array}$ & $\begin{array}{c}\text { Ferulic } \\
\text { acid }\end{array}$ & $\begin{array}{c}\text { Combined } \\
\text { total }\end{array}$ & $\begin{array}{c}p \text {-coumaric } \\
\text { acid }\end{array}$ & $\begin{array}{l}\text { Ferulic } \\
\text { acid }\end{array}$ & $\begin{array}{c}\text { Combined } \\
\text { total }\end{array}$ \\
\hline Initial & 51.5 & 30.8 & 82.3 & 52.9 & 37.7 & 90.6 \\
\hline 0.5 & 62.7 & 32.9 & 95.6 & 55.0 & 35.1 & 90.1 \\
\hline 1.0 & 58.0 & 32.4 & 90.4 & 48.7 & 31.7 & 80.4 \\
\hline 5.5 & 71.3 & 25.9 & 97.2 & 63.2 & 26.9 & 90.1 \\
\hline 9.5 & 52.7 & 21.9 & 74.6 & 36.4 & 28.9 & 65.3 \\
\hline 13.0 & 56.4 & 28.3 & 84.7 & 39.7 & 21.1 & 60.8 \\
\hline 23.0 & 73.2 & 22.3 & 95.5 & 104.4 & 45.6 & 150.0 \\
\hline
\end{tabular}


from a Georgia salt marsh (Hodson et al. 1984). Initial concentrations of lignin did not differ significantly (ttest) among the 4 types of litter used in this study.

Loss rates of lignin from litter of Spartina alterniflora were greatest during the first month of decomposition (Fig. 5a). During this period, 20 to $35 \%$ of the original amounts of lignin were lost. Such losses may reflect rapid microbial catabolism of lignin. In studies of decomposition of $\left[{ }^{14} \mathrm{C}\right]$ lignocelluloses from $S$ alterniflora, Maccubbin \& Hodson (1980) demonstrated that microbial degradation of lignin occurs within hours of microbial colonization of detrital material, and Wilson (1985) found rates of decomposition of lignin peaked in the first $4 \mathrm{~d}$ of decomposition. These early, rapid losses of lignins may indicate removal of protolignin (a precursor of lignin proper; Sakakibara 1977), or of the more labile or exposed lignin fractions (Albert \& Boudet 1979, Odier \& Monties 1983).

The rate of disappearance of lignin slowed during the winter and increased again in the spring and summer (Fig. 5a). Rates of loss of lignins during this period, however, were always slower than those observed during the first month of decomposition. A decrease in rates of mineralization of lignins with time has also been observed in radiotracer studies (Maccubbin \& Hodson 1980, Hodson et al. 1984, Wilson 1985), presumably due to the increasing recalcitrance of the remaining lignocelluloses to microbial degradation as the more labile constituents are consumed (Benner et al. 1984). After 1 yr of decomposition, little further loss of lignin occurred in control litters, and in one case (LM XF) the amount of lignin remaining apparently doubled over the second year. The increase in amount of lignin remaining in LM XF litter coincided with an increase in AFDW (see Fig. 1), and may merely reflect the AFDW increase as \% lignin of AFDW in LM XF litter did not change dramatically in relation to $\%$ lignin in other litter types during the second year.

The relative concentration of lignin in the litter increased throughout the study period (Fig. 5b). An increase of $2 \%$ in relative concentration of lignin was observed over 1 mo of decomposition of field-incubated litter, slightly less than the $4.8 \%$ increase in relative lignin concentration occurring in a month calculated from results of radiotracer experiments on similar litter (Wilson 1985). The slower rate of increase in lignin concentrations in field-incubated litter may reflect lower temperatures in the field, or result from the use of whole litter in litter bag experiments and ground litter (particle size $<0.425 \mathrm{~mm}^{2}$ ) in the radiotracer experiment (Wilson 1985). Decreasing particle size is known to be an important factor increasing rates of lignocellulose mineralization (Hodson et al. 1983).

The gradual increase in relative concentration of lignin in the litter reflects the slower breakdown of lignin compared to other (mainly polysaccharide) fractions (Minderman 1968, Toth et al. 1975). More rapid mineralization of the structural polysaccharide component compared to the lignin component of lignocelluloses has also been observed in radiotracer studies of decomposition of lignocelluloses of Spartina alterniflora (Maccubbin \& Hodson 1980, Hodson et al. 1984, Wilson 1985). Continual increase in concentrations of lignins and other refractory residues and concomitant decrease of the more labile fractions renders the remaining litter progressively more resistant to decay (Hodson et al. 1984). Eventually, only very refractory components were left, and loss of organic matter nearly ceased.

In this study, lignin concentrations were determined by UV absorption following lignin digestion with acetyl bromide. Previous studies have generally employed the method of Van Soest (1963) for lignin determinations in decaying litter (Triska et al. 1975 , Suberkropp et al. 1976, Godshalk \& Wetzel 1978a, $1978 \mathrm{~b})$, although this technique potentially overestimates lignin concentrations since complexes formed by the binding of nitrogenous compounds by phenolics (Handley 1961, Van Sumere et al. 1975, Swift et al. 1979) are reported as lignin (Suberkropp et al. 1976). Lignin determinations by the UV absorption method are not subject to such interference (Morrison 1972a, $1972 b)$, but do assume that the molar absorptivity $\left(\varepsilon_{280}\right)$ of the residual lignin is unaltered by decay (Crawford 1981). Although this requirement may not be completely satisfied, comparison of the lignin oxidation product composition of newly senesced culms of Spartina alterniflora with that of 23 mo old litter shows that little change in lignin composition occurred over 2 yr of decomposition of litter (Wilson et al. 1985).

Comparison of lignin concentrations in litter of Spartina alterniflora determined by the Van Soest technique (Wilson 1985) with lignin concentrations determined by the UV absorption method, however, indicated that there was a good correlation ( $r=0.92$; $\mathrm{p}<0.001$ ) and close 1:1 correspondence between lignin concentrations determined by the 2 methods (as determined by a linear regression of the lignin concentrations determined by each method on one another; a t-test showed the slope of the regression did not differ significantly from a slope of 1). Both techniques yielded similar results.

\section{Litter mass loss}

The pattern of initial rapid loss of weight, a slower rate of loss of more resistant material, and an even slower loss of the most recalcitrant fractions has been noted previously in decomposition curves (Odum et al. 
1973, Valiela et al. 1985). The early losses were generally attributed to leaching, but certain soluble components of litter such as soluble phenolics and soluble carbohydrates can also combine with structural phenolics and polysaccharides to yield insoluble, stable complexes that are resistant to decay (Suberkropp et al. 1976, Bon \& Haverkamp 1982). Such complex formation may in part account for the disappearance of the soluble components of the litter and absolute increases in bound phenolics and lignins (Fig. 4 \& 5).

The disappearance of 20 to $30 \%$ of the initial content of cell wall material within the first $30 \mathrm{~d}$ of decay indicated that appreciable microbial decomposition of structural components occurred during the 'leaching' phase (Fig. 3). Concurrent loss of a soluble organic fraction and an insoluble intermediately-available organic fraction also occurs in wheat straw litter (Reinertsen et al. 1984). These losses dominated the initial stages of straw decomposition. Loss of cellulose, an insoluble structural component of plant cell walls, was observed during the initial phase of decomposition of litter of Spartina alterniflora (Wilson 1985).

\section{Relation of initial substrate quality to decay}

The importance of substrate quality as a regulator of the process of decomposition was recognized early (Waksman 1929, Mikola 1955, Minderman 1968). In particular, several recent studies have related biodegradability of plant litter to initial contents of lignin and nitrogen. For instance, in a study of decomposition of forest litter, Fogel \& Cromack (1977) found that the initial lignin concentration of the litter substrate was highly correlated with decay rate. Marinucci et al. (1983) demonstrated a direct relation between initial nitrogen content and decay rates of litter of Spartina alterniflora in laboratory percolators. Melillo et al. (1982) noted that the initial content of lignin and the ratio of lignin to nitrogen were highly correlated with rates of decay of litter in a hardwood forest. In this study, initial concentrations of lignin did not vary significantly among litter types and so could not contribute to the variability in decay rates of the litters. Initial concentrations of nitrogen, however, varied more widely among the 4 types of litter, with a range of $0.9 \% \mathrm{~N}$ (LM C litter) to $1.8 \% \mathrm{~N}$ (LM F litter). Initial nitrogen content of litter was a significant predictor (Pearson product-moment correlation coefficient) of the percent AFDW remaining after 5.5 mo of decomposition ( $\mathrm{r}=-0.746 ; \mathrm{P}<0.05$ ), by which time 35 to $65 \%$ of the total weight loss had occurred. Thus, over this period of decomposition, these results are consistent with those of Marinucci et al. (1983). Similarly,
Benner et al. (1985) found a strong positive correlation between initial nitrogen content of several plant species, including $S$. alterniflora, and rates of lignocellulose decomposition over the course of a 1 mo laboratory incubation experiment.

Initial content of nitrogen, however, was not a significant predictor of decay rates in the later stages of decomposition. Neither the percentage AFDW remaining, nor the decomposition rate constant, $k\left(\mathrm{~d}^{-1}\right)$, were correlated with initial $\mathrm{N}$ content after 13 or 23 mo of decomposition. The litter with the highest initial $N$ content actually increased in AFDW during the second year of decomposition (Fig. 1).

\section{Relation of nitrogen and lignin contents to decay rate}

The rate of decomposition of litter of Spartina alterniflora was influenced by the chemical composition of the litter, despite a paucity of correlations between initial chemical quality of litter and decomposition rates. Following the rapid loss of soluble and insoluble substances from litter during the early phase of decomposition, concentrations of structural components increased and began to dominate long-term decomposition. During the decomposer and refractory phases of decomposition, lignin and nitrogen concentrations of the litter at the beginning of each sampling interval were inversely correlated with daily weight loss occurring during that interval (Fig. 6; $r=-0.532, p<0.05$ and $r=-0.523, p<0.05$, respectively). The gradual enrichment of litter in lignin evidently masks other structural components from enzymatic attack, renders the remaining litter increasingly more resistant to decomposition, and slows decay rates over time.

Concentrations of nitrogen were inversely correlated with the percentage of original biomass remaining in a study of the decomposition of leaf litter in a hardwood forest (Aber \& Melillo 1980). We also observed an inverse relation to nitrogen $(r=-0.773 ; p<0.01)$ and a quite good inverse relation to lignin concentration $(r=-0.887 ; p<0.001)$ during the decomposer phase (Fig. 7). In the second year of decay, however, this relation failed since there was little change in the amount remaining, although the nitrogen and lignin content continued to increase.

The accumulation of nitrogen in litter has been observed frequently during decay (Odum et al. 1973, Rice \& Tenore 1981, Melillo et al. 1982), but the mechanisms of nitrogen accumulation have not been fully documented. Absolute increases in litter nitrogen were originally attributed to increases in microbial protein during decay (Newell 1965, Odum \& de la Cruz 1967). More recently, investigations have demonstrated the presence of non-protein nitrogen in plant 


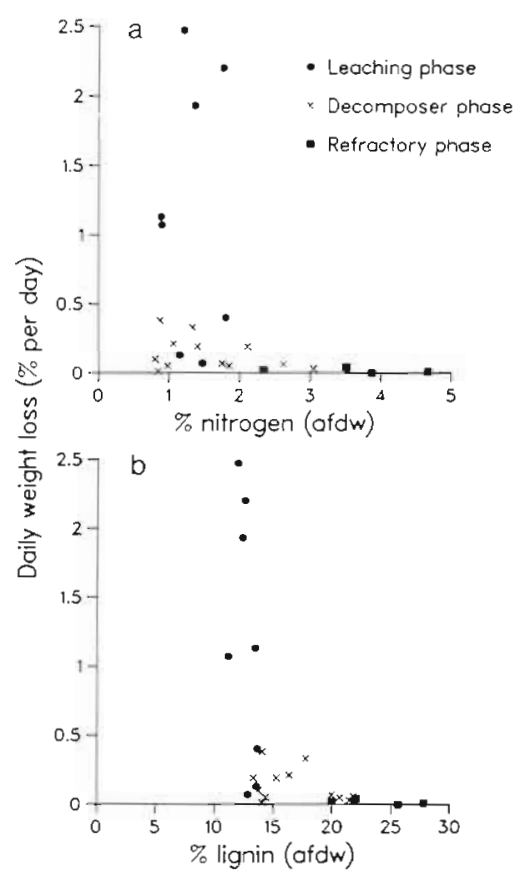

Fig. 6. Rate of litter decomposition (\% AFDW loss $d^{-1}$ ) occurring within each sampling interval expressed as a function of (a) percent nitrogen concentration and (b) percent lignin concentration, at the beginning of that interval for the 3 phases of decay: leaching phase, 0 to $30 \mathrm{~d}_{\text {; }}$ decomposer

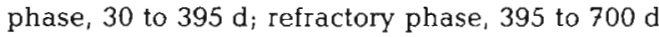

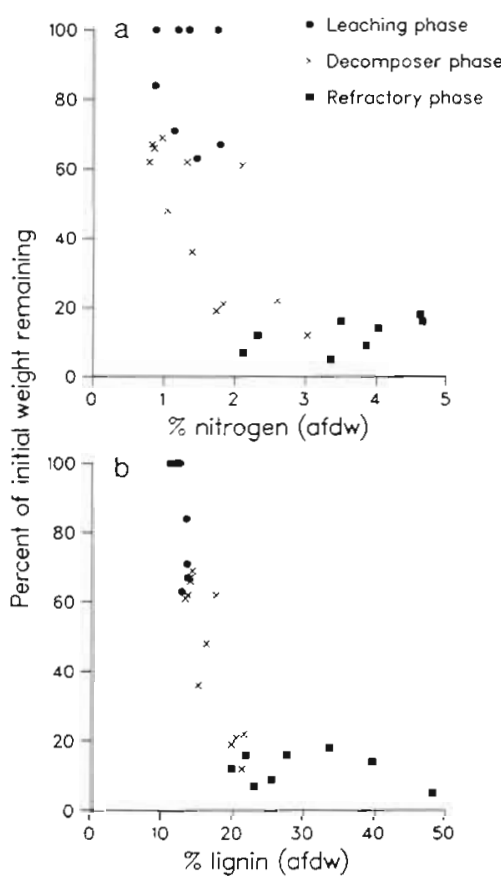

Fig. 7. Decomposition of litter of Spartina alterniflora with the $\%$ AFDW remaining expressed as a function of (a) percent nitrogen concentration and (b) percent lignin concentration in the remaining litter litter (Suberkropp et al. 1976, Odum et al. 1979) and have suggested that microbial and fungal biomass account for less than $20 \%$ of the nitrogen present in decaying litter of Spartina alterniflora (Rublee et al. 1978, Lee et al. 1980, Marinucci 1982, Hicks 1983). Fungi contributed the major portion of microbial nitrogen in Spartina litter (Lee et al. 1980, Newell \& Hicks 1982, Marinucci et al. 1983).

The condensation of reactive phenolics and carbohydrates with proteins and other products of microbial activity provides an alternative explanation for the accumulation of nitrogen in litter (Rice 1982, Rice \& Hanson 1984, Melillo et al. 1984). During decomposition, the depolymerization of the litter substrate by microbial enzymes results in an enrichment in reactive carbohydrate, phenolic, amino, and polypeptide groups which can combine to yield complex nitrogenenriched condensates. Exoenzymes and other microbial exudates (e.g. mucopolysaccharides) become incorporated in the humifying matrix of the decomposing litter as nitrogenous complexes synthesized by condensation reactions with reactive phenols, carbohydrates, and lignins. As decay continues, the litter becomes increasingly enriched in these recalcitrant nitrogen-enriched complexes, and rates of decay slow. This explanation is supported by observations of the apparent complexation of soluble phenolics in LM litter during the early stages of decomposition, as indicated by the absolute gains in bound phenolics occurring concurrently (cf. Fig. 4 \& 2), and by the strong positive correlation between increasing concentrations of lignin and nitrogen in decomposing litter of Spartina alterniflora $(\mathrm{r}=0.789 ; \mathrm{p}<0.001)$.

We postulated that the rate of decomposition of litter was influenced by the chemistry of the litter substrate. The correlation between litter decay rate and lignin content indicated the potential for significant influence of lignin content on decay during the decomposer and refractory phases of litter decomposition. Nitrogen content of litter increased during decomposition and was inversely related to rates of litter decay. The increase was attributed to the sequestration of nitrogen in refractory complexes by condensation reactions. Soluble and bound phenolics were apparently involved in the formation of these stable, resistant complexes. Further experiments are needed to investigate the interactions of phenolics, carbohydrates, and nitrogen in decomposing litter of Spartina alterniflora and to assess the significance of reductions of 'available nitrogen' by complex formation on the activities of decomposers and on growth of detritivores.

Acknowledgements. We thank Sarah Allen, Richard Van Etten, Robin Harrington, Suzanne Volkmann, and Norma Butler for their assistance with the field work. We greatly 
appreciate the constructive comments of 3 reviewers on earlier drafts of this paper. We are grateful to Salt Pond Sanctuaries and Dorothea and the late Arnold Gifford for use of their land on Great Sippewissett salt marsh. This work was supported by National Science Foundation grants DEB7905127 and BSR-827040.

\section{LITERATURE CITED}

Aber, J. D., Melillo, J.M. (1980). Litter decomposition: measuring state of decay and percent transfer into forest soils. Can. J. Bot. 58: 416-421

Akers, S. W., Anderson, C. E., Blum, U. (1977). Characterization of vacuolar bodies in Spartina alterniflora. II. Some physical and chemical properties. Am. J. Bot. 64: 641-648

Albert, G., Boudet, A. (1979). La lignification chez le Peuplier. II. Estimation des flux métaboliques impliqués dans la biosynthèse des monomères des lignines. Physiol. Veg. 17: 75-82

Benner, R., Maccubbin, A. E., Hodson, R. E. (1984). Preparation, characterization, and microbial degradation of specifically radiolabeled $\left[{ }^{14} \mathrm{C}\right]$ lignocelluloses from marine and freshwater macrophytes. Appl. environ. Microbiol. 47: 381-389

Benner, R., Moran, M. A., Hodson, R. E. (1985). Effects of pH and plant source on lignocellulose biodegradation rates in two wetland ecosystems, the Okeefenokee Swamp and a Georgia salt marsh. Limnol. Oceanogr. 30: 489-499

Bollen, W. B. (1953). Mulches and soil conditioners. Carbon and nitrogen in farm and forest products. Agric. Fd. Chem. 7: $379-381$

Boon, J. J., Haverkamp, J. (1982). Pyrolysis mass spectrometry of intact and decomposed leaves of Nuphar variegatum and Zostera marina, and some archeological eelgrass samples. Hydrobiologia 16: 71-82

Brock, T. C. M., De Lyon, M. J. H., Van Laar, E. M. J. M., Van Loon, E. M. M. (1985). Field studies on the breakdown of Nuphar lutea (L.) Sm. (Nymphaeaceae), and a comparison of three mathematical models for organic weight loss. Aquat. Bot. 21: 1-22

Buchsbaum, R., Valiela, I., Swain, T. (1984). The effect of phenolic and other constituents on feeding by Canada geese in a coastal marsh. Oecologia (Berl.) 63: 343-349

Christian, R. R. (1984). A life-table approach to decomposition studies. Ecology 65: 1693-1697

Collins, P. J., Wilson, J. O., Swain, T. (1981). The importance of hydroxycinnamic acids in the decomposition of salt marsh litter. In: Fuchsman, C. (ed.) Proceedings of the International Peat Symposium. Bemidji University, Bemidji, Minnesota, p. 157-175

Cowling, E. B., Brown, W. (1969). Structural features of cellulosic materials in relation to enzymatic hydrolysis. In: Hajny, G. J., Reese, E. T. (ed.) Cellulases and their applications. Adv. Chem. Ser. Publ. No. 95, Amer. Chem. Soc., Washington, DC

Crawford, R. L. (1981). Lignin biodegradation and transformation. John Wiley and Sons, New York

Davies, R. I. (1971). Relation of polyphenols to decomposition of organic matter and to pedogenetic processes. Soil Sci. 111: $80-85$

Effland, M. J. (1977). Modified procedure to determine acidinsoluble lignin in wood and pulp. Tappi 60: 143-144

Fogel, R., Cromack, K., Jr. (1977). Effect of habitat and substrate quality on Douglas fir litter decomposition in western Oregon. Can. J. Bot. 55: 1632-1640

Godshalk, G. L., Wetzel, R. G. (1978a). Decomposition of aquatic angiosperms. I. Dissolved components. Aquat. Bot. 5: 281-300

Godshalk, G. L., Wetzel, R. G. (1978b). Decomposition of aquatic angiosperms. II. Particulate components. Aquat. Bot. 5: 301-327

Haines, E. B., Hanson, R. B. (1979). Degradation of detritus from Spartina, Salicornia, and Juncus. J. exp. mar. Biol. Ecol. 40: 27-40

Handley, W. R. C. (1961). Further evidence for the importance of residual leaf protein complexes in litter decomposition and the supply of nitrogen for plant growth. Plant Soil 15: $37-73$

Harrison, P. G. (1982). Control of microbial growth and of amphipod grazing by water soluble compounds from leaves of Zostera marina. Mar. Biol. 67: 225-230

Hartley, R. D., Jones, E. C. (1977). Phenolic components and degradability of cell walls of grass and legume species. Phytochemistry 16: 1531-1534

Hicks, R. E. (1983). Microbial growth during the initial decomposition of Spartina alterniflora leaves. Ph. D. dissertation, Univ. of Georgia, Athens

Hodson, R. E., Benner, R., Maccubbin, A. E. (1983). Transformations and fate of lignocellulosic detritus in marine environments. In: Oxley, T. A., Barry, S. (ed.) Biodeterioration 5. John Wiley, Chichester, p. 185-195

Hodson, R. E., Christian, R. R., Maccubbin, A. E. (1984). Lignocellulose and lignin in the salt marsh grass Spartina alterniflora: initial concentrations and short-term, postdepositional changes in detrital matter. Mar. Biol. 81: 1-7

Johnson, D. B., Moore, W. E., Zank, L. C. (1961). The spectrophotometric determination of lignin in small wood samples. Tappi 44: 793-798

Kaushik, N. K., Hynes, H. B. N. (1968). Experimental study on the role of autumn-shed leaves in aquatic environments. J. Ecol. 56: 229-243

King, H. G. C., Heath, G. W. (1967). The chemical analysis of small samples of leaf material and the relationship between the disappearance and composition of leaves. Pedobiologia 7: 192-197

Lee, C., Howarth, R., Howes, B. (1980). Sterols in decomposing Spartina alterniflora and the use of ergosterol in estimating the contribution of fungi to detrital nitrogen. Limnol. Oceanogr. 25: 290-303

Maccubbin, A. E., Hodson, R. E. (1980). Mineralization of detrital lignocelluloses by salt marsh sediment microflora. Appl. environ. Microbiol. 40: 735-740

Marinucci, A. C. (1982). Carbon and nitrogen fluxes during decomposition of Spartina alterniflora in a flow-through percolator. Biol. Bull. mar. biol. Lab., Woods Hole 162: $54-69$

Marinucci, A. C., Hobbie, J. E., Helfrich, J. V. K. (1983). Effect of litter nitrogen on decomposition and microbial biomass in Spartina alterniflora. Microb. Ecol. 9: 27-40

Meentemeyer, V. (1978). Macroclimate and lignin control of decomposition rates. Ecology 59: 465-472

Melillo, J. M., Aber, J. D., Muratore, J. F. (1982). Nitrogen and lignin control of hardwood leaf litter decomposition dynamics. Ecology 63: 621-626

Melillo, J. M., Naiman, R. J., Aber, J. D., Linkins, A. E. (1984). Factors controlling mass loss and nitrogen dynamics of plant litter decaying in northern streams. Bull. mar. Sci. 35: $341-356$

Mikola, P. (1955). Experiments on the rate of decomposition of forest litter. Comm. Inst. For. Fenn. 43: 1-50

Minderman, G. (1968). Addition, decomposition, and accumulation of organic matter in forests. J. Ecol. 56: 355-362 
Montagna, P. A., Ruber, E. (1980) Decomposition of Spartina alterniflora in different seasons and habitats of a northern Massachusetts salt marsh and a comparison with other Atlantic regions. Estuaries 3: 61-64

Morrison, I. M. (1972a). A semi-micro method for the determination of lignin and its use in predicting the digestibility of forage crops. J. Sci. Fd. Agric. 23: 455-463

Morrison, I. M. (1972b). Improvements in the acetyl bromide technique to determine lignin and digestibility and its application to legumes. J. Sci. Fd. Agric. 23: 1463-1469

Newell, R. (1965). The role of detritus in the nutrition of two marine deposit feeders, the prosobranch Hydrobia ulvae and the bivalve Macoma balthica. Proc. zool. Soc. 144 : $25-45$

Newell, S. Y., Hicks, R. E. (1982). Direct-count estimates of fungal and bacterial biovolume in dead leaves of smooth cordgrass (Spartina alterniflora Loisel). Estuaries 5: 246-260

Nykvist, N. (1959). Leaching and decomposition of litter. I. Experiments on leaf litter of Fraxinus excelsior. Oikos 10: 190-209

Odier, E., Monties, B. (1983). Absence of microbial mineralization of lignin in anaerobic enrichment cultures. Appl. environ. Microbiol. 46: 661-665

Odum, E. P., de la Cruz, A. A. (1967). Particulate detritus in a Georgia salt marsh-estuarine ecosystem. In: Lauff, G. H. (ed.) Estuaries. Am. Assoc. Adv. Sci., Washington, DC, p. 383-388

Odum, W. E., Heywood, M. A. (1978). Decomposition of intertidal marsh plants. In: Good, R. E., Whigham, D. F., Simpson, R. L., Jackson, C. G. (ed.) Freshwater wetlands, ecological processes and management potential. Academic Press, New York, p. 89-97

Odum, W. E., Kirk, P. W., Zieman, J. C. (1979). Non-protein nitrogen compounds associated with particles of vascular plant detritus. Oikos 32: 363-367

Odum, W. E., Zieman, J. C., Heald, E. J. (1973). The importance of vascular plant detritus to estuaries. In: Chabreck, R. H. (ed.) Proceedings of the coastal marsh and estuary symposium. L.S.U. Div. Cont. Educ., Baton Rouge, p. $91-135$

Olson, J. S. (1963). Energy storage and the balance of producers and decomposers in ecological systems. Ecology 44: $322-331$

Peevy, W. S., Norman, A. G. (1948). Influence of plant materials on properties of the decomposed residue. Soil Sci. 65 : 209-226

Reinertsen, S. A., Elliott, L. F., Cochran, V. L., Campbell, G. S. (1984). Role of available carbon and nitrogen in determining the rate of wheat straw decomposition. Soil Biol. Biochem. 16: 459-464

Rice, D. L. (1982). The detritus nitrogen problem. New observations and perspectives from organic geochemistry. Mar. Ecol. Prog. Ser. 9: 153-162

Rice, D. L., Hanson, R. B. (1984). A kinetic model for detritus nitrogen: role of the associated bacteria in nitrogen accumulation. Bull. mar. Sci. 35: 326-340

Rice, D. L., Tenore, K. R. (1981). Dynamics of carbon and nitrogen during the decomposition of detritus derived from estuarine macrophytes. Estuar. coast. Shelf Sci. 13: 681-690

Rice, E. L., Pancholy, S. K. (1974). Inhibition of nitrification by climax ecosystems. III. Inhibitors other than tannins. Am. J. Bot. 61: 1095-1103

Rublee, P., Cammen, L., Hobbie, J. E. (1978). Bacteria in a North Carolina salt marsh: Standing crop and importance in the decomposition of Spartina alterniflora. Univ. of North Carolina Sea Grant Publ. UNC-SG-78-11

Sakakibara, A. (1977). Degradation products of protolignin and the structure of lignin. Rec. Adv. Phytochem. 11: $117-139$

Satchell, J. E., Lowe, D. G. (1967). Selection of leaf litter by Lumbricus terrestris. In: Graff, O., Satchell, J. E. (ed.) Progress in soil biology. North Holland, Amsterdam, p. 102-109

Schlesinger, W. H. (1977). Carbon balance in terrestrial detritus. A. Rev. Ecol. Syst. 8: 51-81

Shea, M. L., Warren, R. S., Niering, W. A. (1975). Biochemical and transplantation studies of the growth forms of Spartina alterniflora on Connecticutt salt marshes. Ecology 56 : $461-466$

Singh, J. S., Gupta, S. R. (1977). Plant decomposition and soil respiration in terrestrial ecosystems. Bot. Rev. 43: 449-528

Stafford, H. A. (1974). Possible multienzyme complexes regulating the formation of $\mathrm{C} 6-\mathrm{C} 3$ phenolic compounds and lignins in higher plants. Rec. Adv. Phytochem. 8: 53-79

Suberkropp, K., Godshalk, G. L., Klug, M. J. (1976). Changes in the chemical composition of leaves during processing in a woodland stream. Ecology 57: 720-727

Suberkropp, K., Klug, M. J., Cummins, K. W. (1975). Community processing of leaf litter in woodland streams. Verh. int. Verein. Limnol. 19: 1653-1658

Swain, T. (1978). Phenolics in the environment. Rec. Adv. Phytochem. 12: 617-640

Swift, M. J., Heal, O. W., Anderson, J. M. (1979). Decomposition in terrestrial ecosystems. Studies in ecology, vol. 5 , Univ. of California Press, Berkeley

Toth, J. A., Papp, L. B., Lenkey, B. (1975). Litter decomposition in an oak forest ecosystem (Quercetum petreae) in northern Hungary studied in the framework of 'Sikfökut Project'. In: Kilbertus, G., Reisinger, O., Mourey, A., Cancela de Fonseca, J. A. (ed.) Biodegradation et humification. Pierrance Editeur, Sarreguemines, France, p. $41-58$

Triska, F. J., Sedell, J. R., Buckley, B. (1975). The processing of conifer and hardwood leaves in two coniferous forest streams. II. Biochemical and nutrient changes. Verh. int Verein. Limnol. 19: 1628-1639

Valiela, I., Koumjian, L., Swain, T., Teal, J. M., Hobbie, J. E. (1979). Cinnamic acid inhibition of detritus feeding Nature, Lond. 280: $55-57$

Valiela, I., Rietsma, C. S. (1984). Nitrogen, phenolic acids, and other feeding cues for salt marsh detritivores. Oecologia (Berl.) 63: 350-356

Valiela, I., Teal, J. M., Deuser, W. G. (1978). The nature of growth forms in the salt marsh grass Spartina alterniflora. Am. Nat. 112: 461-470

Valiela, 1., Teal, J. M., Persson, N. Y. (1976). Production and dynamics of experimentally enriched salt marsh vegetation: belowground biomass. Limnol. Oceanogr. 21: 245-252

Valiela, I., Teal, J. M., Allen, S. D., Van Etten, R., Goehringer, D., Volkmann, S. (1985). Decomposition in salt marsh ecosystems: The phases and major factors affecting disappearance of above-ground organic matter. J. exp. mar. Biol. Ecol. 89: 29-54

Valiela, I., Wilson, J., Buchsbaum, R., Rietsma, C., Bryant, D. Foreman, K., Teal, J. M. (1984). Importance of chemical composition of salt marsh litter on decay rates and feeding by detritivores. Bull. mar. Sci. 35: 326-340

Van Soest, P. J. (1963). Use of detergents in the analysis of fibrous feeds. II. A rapid method for the determination of fiber and lignin. J. Ass. off. agric. Chem. 49: 546-551 
Van Sumere, C. F., Albrecht, J., Dedonder, A., De Pooter, H. Pé, I. (1975). Plant proteins and phenolics. In: Harborne, J. B., Van Sumere, C.F. (ed.) The chemistry and biochemistry of plant proteins. Academic Press, New York, p. 211-264

Vande Casteele, K., De Pooter, H., Van Sumere, C. F. (1976). Gas chromatographic separation and analysis of trimethylsilyl derivatives of some naturally occurring nonvolatile phenolic compounds and related substances. J. Chromatogr. 121: 49-63

Vince, S. W., Valiela, I., Teal, J. M. (1981). An experimental study of the structure of herbivorous insect communities in a salt marsh. Ecology 62: 1662-1678

Waksman, S. A. (1929). Chemical and microbiological principles underlying the decomposition of green manure in soils. J. Am. Soc. Agronomy 21: 1-19

White, D. A., Trapani, J. M. (1982). Factors influencing disappearance of Spartina alterniflora from litterbags. Ecology 63: $242-245$

Wieder, R. K., Lang, G. E. (1982). A critique of the analytical methods used in examining decomposition data obtained from litter bags. Ecology 63: 1636-1642
Wiegert, R. G., McGinnis, J. T. (1975). Annual production and disappearance of detritus on three South Carolina old fields. Ecology 56: 129-140

Wilson, J. O. (1985). Decomposition of $\left[{ }^{14} \mathrm{C}\right]$ lignocelluloses of Spartina alterniflora and a comparison with field experiments. Appl. environ. Microbiol. 49: 478-484

Wilson, J. O., Valiela, I., Swain, T. (1985). Sources and concentrations of vascular plant material in sediments of Buzzards Bay, Massachusetts, U.S.A. Mar. Biol. 90: 129-137

Witkamp, M. (1966). Decomposition of leaf litter in relation to environment, microflora, and microbial respiration. Ecology $47: 194-201$

Witkamp, K., van der Drift, J. (1961). Breakdown of forest litter in relation to environmental factors. Plant Soil 15: 295-311

Woodhead, S., Cooper-Driver, G. (1979). Phenolic acids and resistance to insect attack in Sorghum bicolor. Biochem. System. Ecol. 7: 309-310

This paper was presented by Dr. G. W. Thayer; it was accepted for printing on November 26, 1985 